\title{
New and rare species of Volvocaceae (Chlorophyta) in the Polish phycoflora
}

\author{
Ewa Anna Dembowska* \\ Department of Hydrobiology, Nicolaus Copernicus University, Lwowska 1, 87-100 Toruń, Poland
}

\section{Abstract}

Seven species of Volvocaceae were recorded in the lower Vistula River and its oxbow lakes, including Pleodorina californica for the first time in Poland. Three species - Eudorina cylindrica, E. illinoisensis and E. unicocca - were found in the Polish Vistula River in the 1960s and 1970s, as well as at present. They are rare species in the Polish aquatic ecosystems. Three species are common both in the oxbow lakes and in the Vistula River: Eudorina elegans, Pandorina morum and Volvox aureus. New and rare Volvocaceae species were described in terms of morphology and ecology; also photographic documentation (light microscope microphotographs) was completed.

Keywords: Pleodorina, Pandorina, Eudorina, biodiversity, phytoplankton, oxbow lake, lower Vistula

\section{Introduction}

The family of Volvocaceae (Chlorophyta, Volvocales) comprises 7 genera: Eudorina, Pandorina, Platydorina, Pleodorina, Volvox, Volvulina and Yamagishiella [1]. The genera Astrephomene and Gonium were excluded from Volvocaceae and they form new families: Goniaceae - based on the ultrastructure of the gelatinous matrix [2] and Tetrabaenaceae (Gonium sociale) based on the cladistic analysis of morphological data [3]. Over the last decades, several new species were identified [4,5] and phylogenetic relationships within this group were determined $[1,6-8]$ owing to modern technologies, such as genetic and molecular analysis.

Volvocaceae is a group of multicellular colonial algae with the number of cells ranging from 8-16 cells in Pandorina, Volvulina, 16-32 cells in Eudorina, Platydorina, Yamagishiella to $32-64$, or even 128 cells in the genus Pleodorina. Colonies consisting of 200 to over 50000 cells represent the genus Volvox. Colonies from the genus Platydorina are flattened, and spherical or oval from other genera. There are no differences between somatic and reproductive cells in the genera of Eudorina and Pandorina, while in Pleodorina, somatic cells are smaller and reproductive cells are larger. In Volvox colonies, somatic functions are separated from reproductive ones, however most of the cells (>99\%) perform somatic functions [1].

\footnotetext{
*Email: dembow@biol.uni.torun.pl

Handling Editor: Andrzej Bodył
}

This is an Open Access digital version of the article distributed under the terms of the Creative Commons Attribution 3.0 License (creativecommons.org/licenses/by/3.0/), which permits redistribution, commercial and non-commercial, provided that the article is properly cited.
Green algae from the family of Volvocaceae are frequently encountered in eutrophic waters. All species from this family live in fresh waters: lakes, ponds, rivers, and even puddles. Coleman [1] reports that out of ca. 200 colonial Volvocaceae in culture collections, $\sim 1 / 3$ came from puddles, $\sim 1 / 3$ - from lakes and rice fields, and $\sim 1 / 3$ - from zygotes in soil samples from watersides.

Most of the Volvocales taxa have a limited geographical range; some occur at only few sites. In recent years, in aquatic ecosystems of the temperate zone, one can observe unexpected expansion of species previously considered to be tropical. Pleodorina indica found in the Czech Republic is one of the examples of this phenomenon [9]. Pandorina morum, Eudorina elegans, Volvox aureus and V. globator have been found relatively frequently in Poland [10].

Ecology and environmental requirements of many Volvocaceae species are still poorly researched. The knowledge about the requirements of these species can be helpful in the assessment of aquatic ecosystems, the rate of the eutrophication process or climate changes on the Earth. Insufficient knowledge about Volvocaceae in Poland results mainly from their low abundance and incidence.

The present studies were undertaken in order to identify Volvocaceae in six eutrophic, shallow oxbow lakes of the Vistula River, in the main channel of the river and in Włocławek Dam Reservoir. All taxa were documented on light microscope (LM) microphotographs.

\section{Material and methods}

In 1994-2000, the research on phytoplankton of the Lower Vistula was conducted between the towns of Wyszogród and Torun (on the 163th $\mathrm{km}$ of the river). The largest reservoir in Poland is located in this area. More details about the study area, water quality, chemical composition and seasonal changes are presented in the paper by Kentzer et al. [11]. 
Tab. 1 Morphometric and physicochemical (min-max range) parameters of the investigated oxbow lakes.

\begin{tabular}{|c|c|c|c|c|c|c|}
\hline & W1 & W2 & W3 & Ma & Pr & P.D. \\
\hline Geographical location & $\mathrm{N} 53^{\circ} 01^{\prime} \mathrm{E} 18^{\circ} 39^{\prime}$ & $\mathrm{N} 53^{\circ} 01^{\prime} \mathrm{E} 18^{\circ} 38^{\prime}$ & $\mathrm{N} 53^{\circ} 01^{\prime} \mathrm{E} 18^{\circ} 39^{\prime}$ & $\mathrm{N} 53^{\circ} 00^{\prime} \mathrm{E} 18^{\circ} 34^{\prime}$ & $\mathrm{N} 53^{\circ} 00^{\prime} \mathrm{E} 18^{\circ} 33^{\prime}$ & $\mathrm{N} 53^{\circ} 01^{\prime} \mathrm{E} 18^{\circ} 30^{\prime}$ \\
\hline Area (ha) & 1.5 & 2.0 & 2.5 & 2.8 & 1.0 & 71 \\
\hline Maximum depth (m) & 1.8 & 1.8 & 2.5 & 2.5 & 2.0 & 1.8 \\
\hline Maximum length (m) & 140 & 172 & 220 & 640 & 160 & 1800 \\
\hline Maximum width (m) & 67 & 103 & 40 & 61 & 100 & 390 \\
\hline SD visibility $(m)$ & $0.45-1.8$ & $0.6-1.8$ & $0.5-2.0$ & $0.4-2.5$ & $0.4-1.3$ & $0.3-1.8$ \\
\hline $\mathrm{T}\left({ }^{\circ} \mathrm{C}\right)$ & $7.6-22.3$ & $7.6-23.2$ & $7.6-22.2$ & $7.9-24.8$ & $7.4-23.1$ & $7.6-25.4$ \\
\hline $\mathrm{pH}$ & $7.5-8.7$ & $7.6-9.9$ & $7.6-8.6$ & $7.9-9.0$ & $7.7-10.5$ & $7.8-9.2$ \\
\hline$E C\left(\mu \mathrm{Scm}^{-1}\right)$ & $598-950$ & $641-1130$ & $56-844$ & $439-1072$ & $413-708$ & $473-775$ \\
\hline $\mathrm{N}-\mathrm{NH}_{4}\left(\mathrm{mg} \mathrm{dm}^{-3}\right)$ & $0.13-0.95$ & $0.13-0.75$ & $0.16-0.45$ & $0.12-0.42$ & $0.16-0.45$ & $0.01-0.75$ \\
\hline $\mathrm{N}-\mathrm{NO}_{3}\left(\mathrm{mg} \mathrm{dm}^{-3}\right)$ & $0.09-0.3$ & $0.09-0.88$ & $0.8-0.25$ & $0.8-0.23$ & $0.11-1.0$ & $0.6-1.2$ \\
\hline $\mathrm{P}-\mathrm{PO}_{4}\left(\mathrm{mg} \mathrm{dm}^{-3}\right)$ & $0-0.23$ & $0-0.25$ & $0.02-0.25$ & $0.01-0.12$ & $0.01-0.18$ & $0-0.08$ \\
\hline $\operatorname{Chl} a\left(\mu \mathrm{g} \mathrm{dm}^{-3}\right)$ & $2.68-58.52$ & $3.97-70.86$ & $3.12-35-24$ & $1.44-73.90$ & $4.48-210.93$ & $4.05-184.14$ \\
\hline
\end{tabular}

Tab. 2 Volvocaceae taxa found at the investigated sites.

\begin{tabular}{|c|c|c|c|c|c|c|c|c|}
\hline & WDR & Vist. & W1 & W2 & W3 & Ma & $\operatorname{Pr}$ & P.D. \\
\hline Eudorina illinoisensis (Kofoid) Pascher ${ }^{*}$ & + & + & + & - & + & - & - & - \\
\hline Eudorina cylindrica Korschikoff* & + & - & - & - & + & + & + & + \\
\hline Eudorina elegans Ehrenberg & + & + & + & + & - & + & + & + \\
\hline Eudorina peripheralis (Goldstein) Yamada and/or & + & + & + & - & + & + & + & - \\
\hline \multicolumn{9}{|l|}{ Yamagishiella unicocca (Rayburn et Starr) Nozaki* } \\
\hline Pleodorina californica Shaw ${ }^{*}$ & + & - & + & - & + & + & + & - \\
\hline Pandorina morum Bory & + & + & + & + & + & + & + & + \\
\hline Volvox aureus Ehrenberg & - & + & + & - & - & + & - & - \\
\hline
\end{tabular}

“+” - present; “-” - absent. * rare species described in the text.

In 2006-2010, the research covered the Vistula River and six oxbow lakes located in the city of Torun (N $53^{\circ} 00^{\prime}-53^{\circ} 01^{\prime}$; E $\left.18^{\circ} 30^{\prime}-18^{\circ} 39^{\prime}\right)$ between the 734 th and 745 th $\mathrm{km}$. Four reservoirs are isolated from the river; two of them are in constant contact with waters of the Vistula River. All reservoirs are shallow - max. depth $2.5 \mathrm{~m}$. Tab. 1. presents morphological and physicochemical parameters of the research sites. The sites are listed in the species description.

A total of 312 phytoplankton samples were collected in the Vistula River and in the Włocławek Reservoir, and 208 samples in the oxbow lakes. Miscellaneous species from the researched family of Volvocaceae were found in the phytoplankton. Phytoplankton was collected from the entire water column with a plankton net No. 25. Samples were preserved with formaldehyde or with Lugol's solution. Live or preserved algae were observed under LM. To examine gelatinous matrix of the colonies methylene blue was used [4,5]. Together with phytoplankton sampling, selected physicochemical water parameters were determined: transparency (SD), temperature (T), $\mathrm{pH}$ and electrolytic conductivity (EC). The content of chlorophyll $a$ (Chl $a$ ) and mineral forms of nitrogen and phosphorus were analyzed in the oxbow lakes.

\section{Results}

In the studied reservoirs seven Volvocaceae taxa were recorded (Tab. 2). All taxa were documented using LM microphotographs (Fig. 1-Fig. 7). More detailed accounts were prepared for the rare species: Eudorina cylindrica, E. illinoisensis, E. peripheralis and/or Yamagishiella unicocca and Pleodorina californica.

\section{Eudorina cylindrica Korschikoff}

Cylindrical coenobia consist of 16 cells arranged in four rows with four cells in each row. Coenobia are 65-70 $\mu \mathrm{m}$ long and $45-50 \mu \mathrm{m}$ wide. Cells are $12-15 \mu \mathrm{m}$ in diameter (Fig. 1).

The species is known from North and South America [1], as well as from Europe: Southern Russia [12], Hungary [13-15] and Romania [16]. In the Vistula River, E. cylindrica was found for the first time in 1968 by Uherkovich [17].

In the phytoplankton of the Lower Vistula researched since 1994, this species was recorded occasionally during spring and summer months, i.e. from May to September 1997, near the dam and at the site in Nieszawa, downstream from the dam [18-20]. 
In the P.D. oxbow lake, E. cylindrica occurred only on 05 August 2008 , when the temperature was $20.8^{\circ} \mathrm{C}$ and the concentration of biogenic elements was as follows: $\mathrm{N}-\mathrm{NH}_{4}$ $0.75 \mathrm{mg} \mathrm{dm}^{-3}, \mathrm{~N}_{-} \mathrm{NO}_{3} 0.2 \mathrm{mg} \mathrm{dm}^{-3}$ and $\mathrm{P}_{-} \mathrm{PO}_{4} 0.08 \mathrm{mg} \mathrm{dm}^{-3}$. In the Prz. reservoir, at the time of isolation from the Vistula River, the species occurred in late August in 2008 and 2009 at a temperature of (respectively) 19.9 and $18.8^{\circ} \mathrm{C}$, and the concentration of N-NH $0.25 \mathrm{mg} \mathrm{dm}^{-3}$ and $1.6 \mathrm{mg} \mathrm{dm}^{-3}, \mathrm{~N}-\mathrm{NO}_{3}$ $0.24 \mathrm{mg} \mathrm{dm}^{-3}$, and $\mathrm{P}_{-} \mathrm{PO}_{4} 0.18 \mathrm{mg} \mathrm{dm}^{-3}$ and $0.3 \mathrm{mg} \mathrm{dm}^{-3}$. In the Ma reservoir, this species occurred in July and August 2010 (2-3

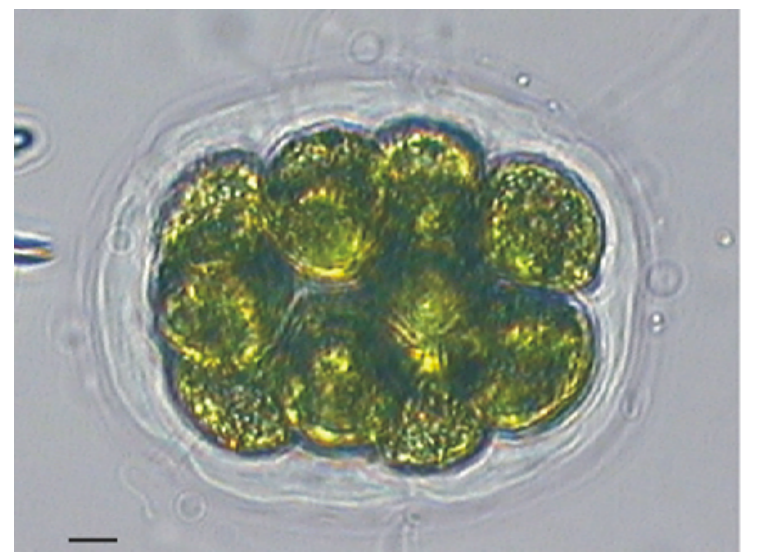

Fig. 1 Eudorina cylindrica Korschikoff. Scale bars: $10 \mu \mathrm{m}$. months after flooding) - at a temperature exceeding $20.5^{\circ} \mathrm{C}$. In the W3 reservoir, E. cylindrica occurred in August 2010 when the temperature fluctuated within the range of $19.6-20.5^{\circ} \mathrm{C}$.

\section{Eudorina illinoisensis (Kofoid) Pascher}

Coenobia are oval shaped, 100-115 $\mu \mathrm{m}$ long and 95-100 $\mu \mathrm{m}$ wide, with 16-64 cells. Large cells are up to $15 \mu \mathrm{m}$ in diameter, small ones - up to $8-11 \mu \mathrm{m}$. There are always 4 small cells at one pole. Cells are facultatively somatic, but they also participate in asexual and sexual reproduction [4] (Fig. 3).
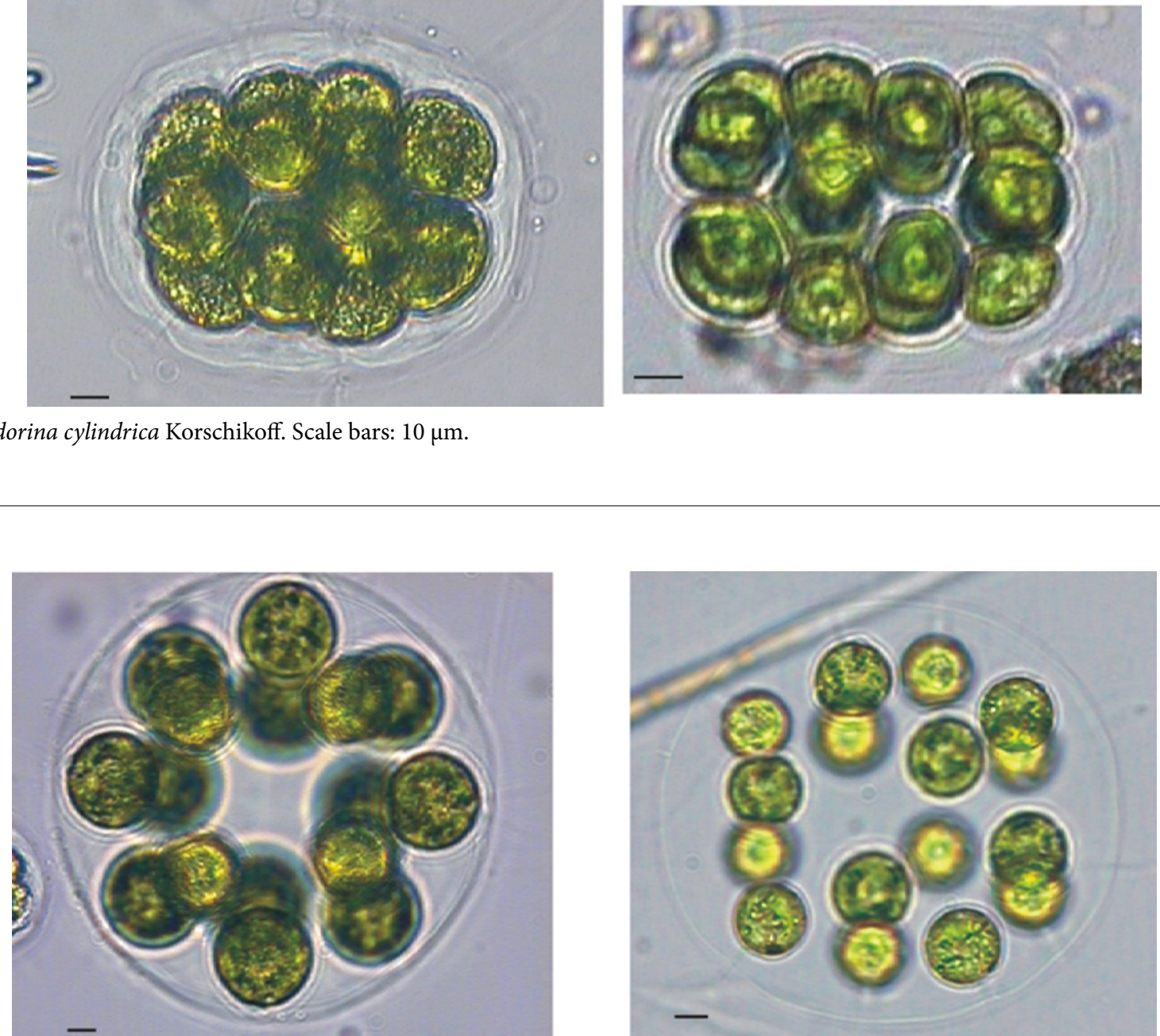

Fig. 2 Eudorina elegans Ehrenberg. Scale bars: $10 \mu \mathrm{m}$.
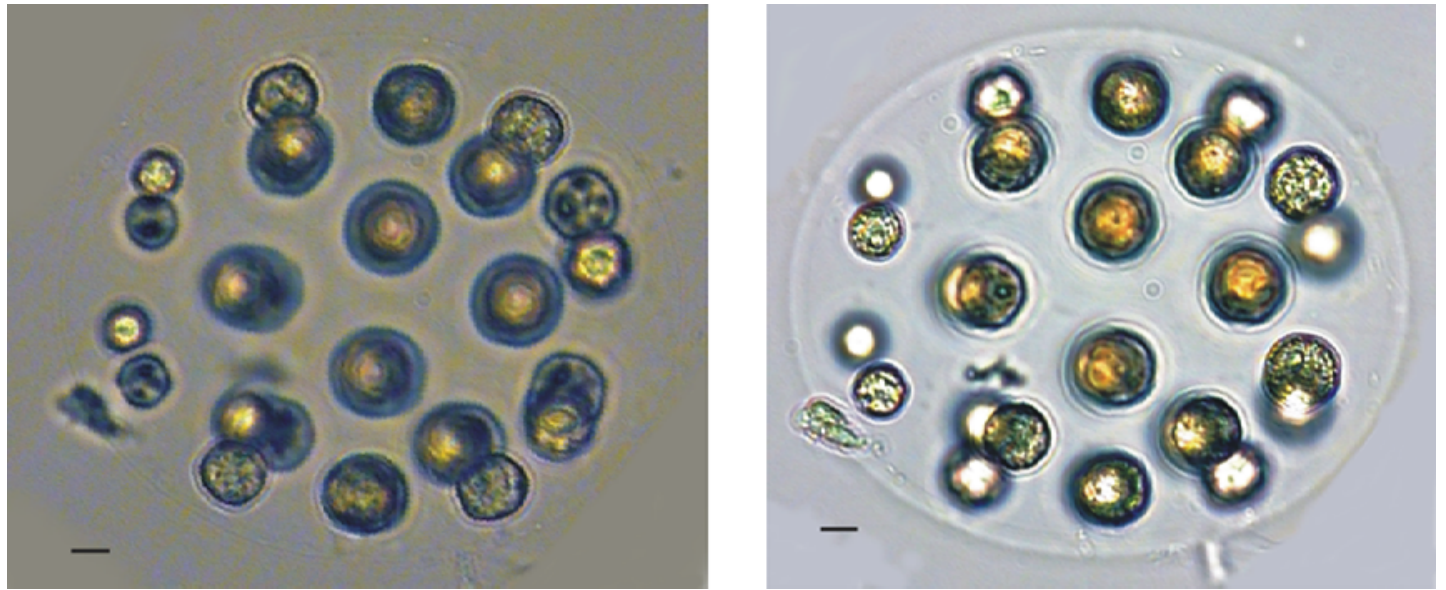

Fig. 3 Eudorina illinoisensis (Kofoid) Pascher. Scale bars: $10 \mu \mathrm{m}$. 
a
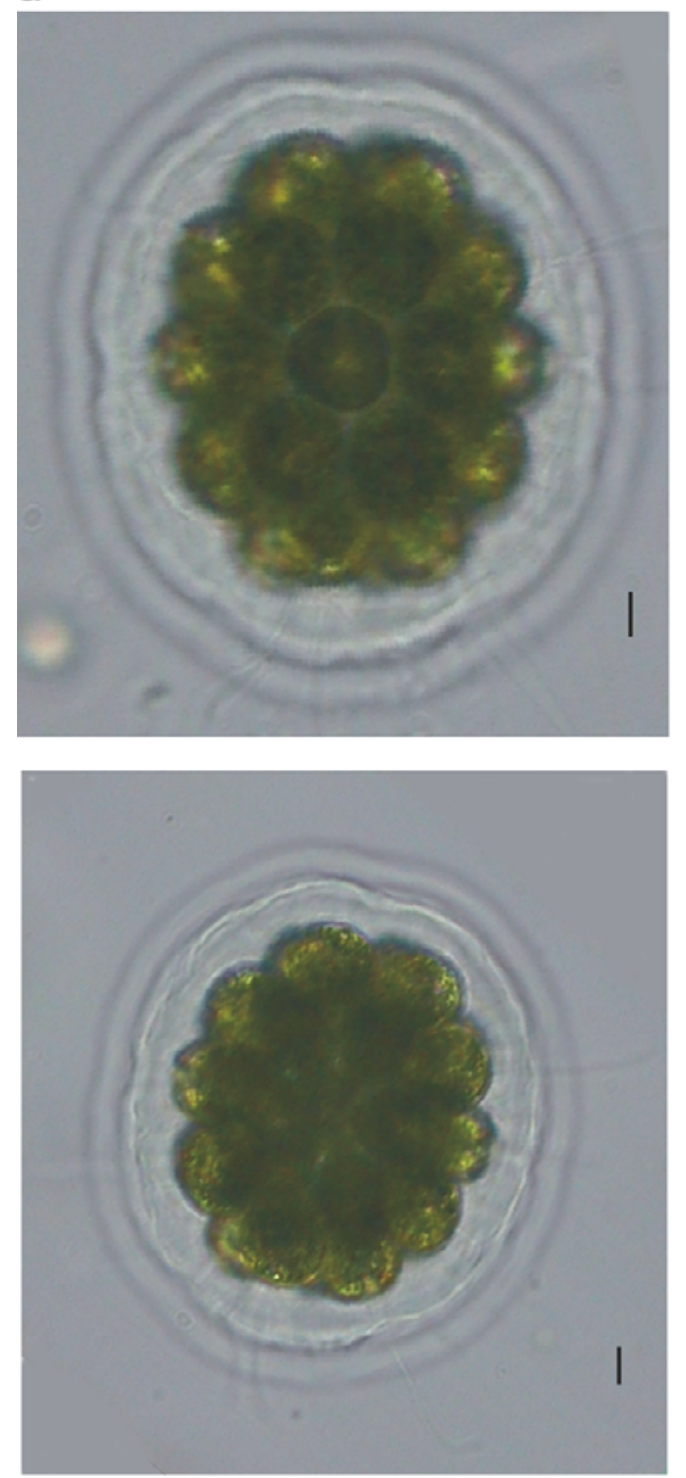

b
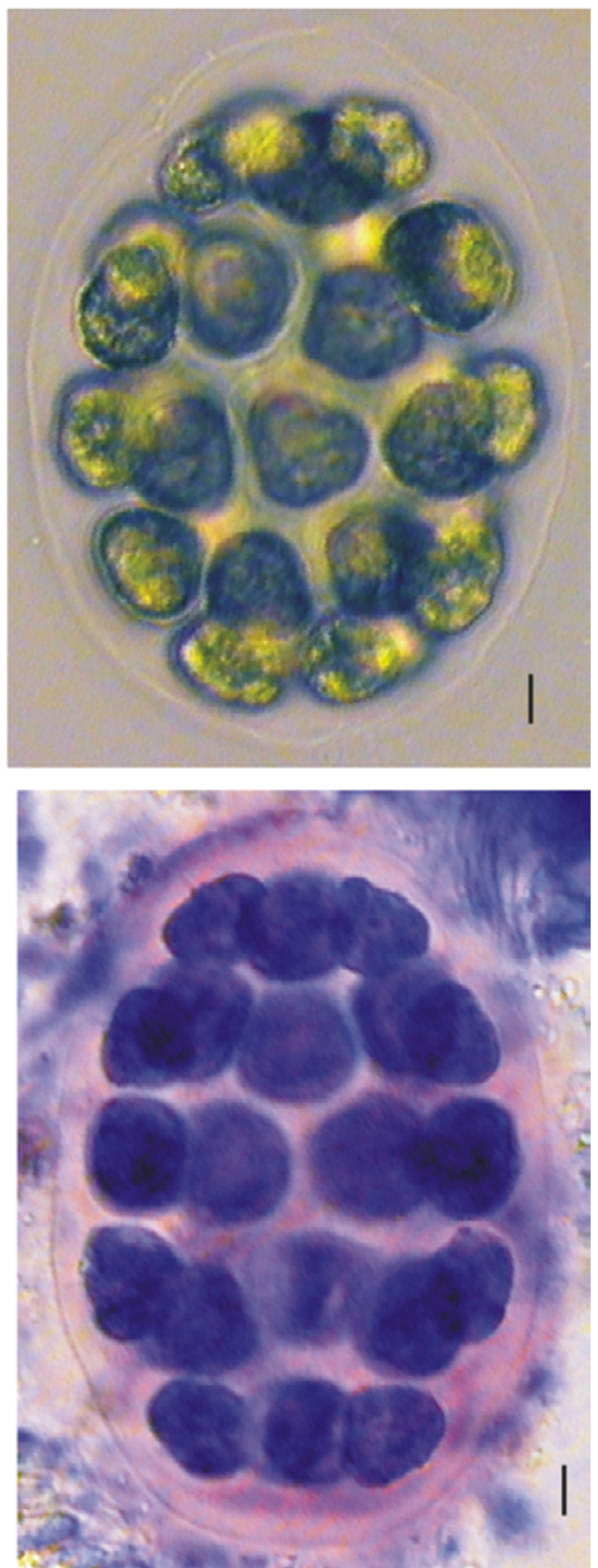

Fig. 4 a Eudorina peripheralis (Goldstein) Yamada and/or Yamagishiella unicocca (Rayburn et Starr) Nozaki. b Eudorina peripheralis (Goldstein) Yamada and/or Yamagishiella unicocca (Rayburn et Starr) Nozaki; picture below after staining with blue methylene. Scale bars: $10 \mu \mathrm{m}$.

The species was recorded in Asia and Europe: in Great Britain [21], Poland [17] and Romania [16], as well as in North and South America: in the region of Great Lakes [22] and in Brazil [23].

The subsequent research in the Vistula River and in the Włocławek Reservoir [18-20] confirmed the presence of this taxon. The species was recorded in spring and summer months, i.e. between May and September every year from 1995 to 2000, at the sites located in the free-flowing river and in WDR. The species occurred at a water temperature exceeding $21^{\circ} \mathrm{C}$ and remained till it dropped to $9.7^{\circ} \mathrm{C}$. In July, the presence of $E$. illinoisensis in the Włocławek Reservoir was accompanied by a water bloom of Microcystis. In reservoir W1, E. illinoisensis was found in July 2010 after the flooding when the temperature fluctuated within the range of $20.6-21.7^{\circ} \mathrm{C}$. In $\mathrm{W} 3$, the species was recorded on 11 August 2010 at a temperature of $19.8^{\circ} \mathrm{C}$.

\section{Eudorina peripheralis (Goldstein) Yamada and/or Yamagishiella unicocca} (Rayburn et Starr) Nozaki

Syn. Pandorina charkowiensis Korschikoff/Pandorina unicocca Rayburn et Starr./Eudorina unicocca G. M. Smith (Fig. 4a,b).

Coenobia are oval shaped, 32-celled, 90-115 $\mu \mathrm{m}$ long and 60-80 $\mu \mathrm{m}$ wide. Spherical cells are $12-18 \mu \mathrm{m}$ long and are arranged in five rows: three central rows consist of 8 cells, two outermost - of 4 cells. Gelatinous matrix is homogeneous. Distinction between species Eudorina peripheralis and Yamagishiella unicocca is possible after determine the number and location of contractile vacuoles in the cell [24]. The publication appeared in 2008 year, when most of the presented material was preserved and observation of the vacuoles was impossible. Earlier Nozaki [25] wrote that it seems impossible to distinguish these two species based on observations of vegetative colonies. 

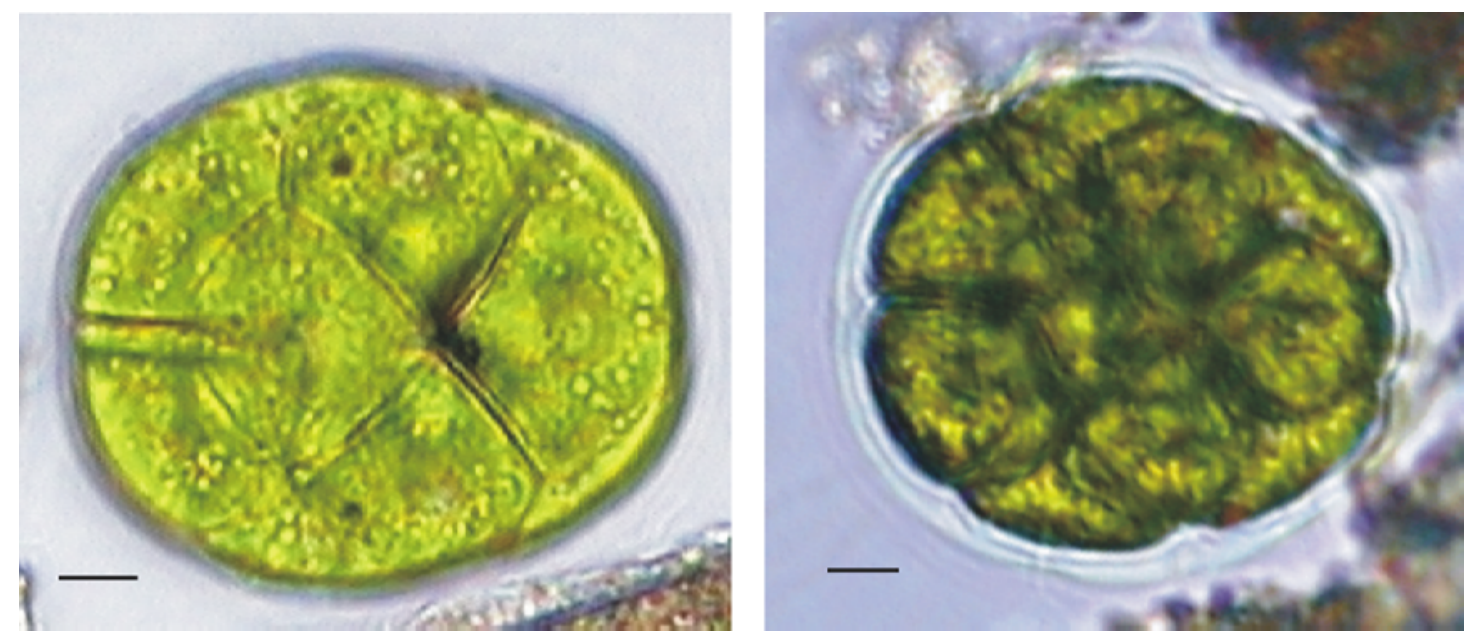

Fig. 5 Pandorina morum Bory. Scale bars $10 \mu \mathrm{m}$.

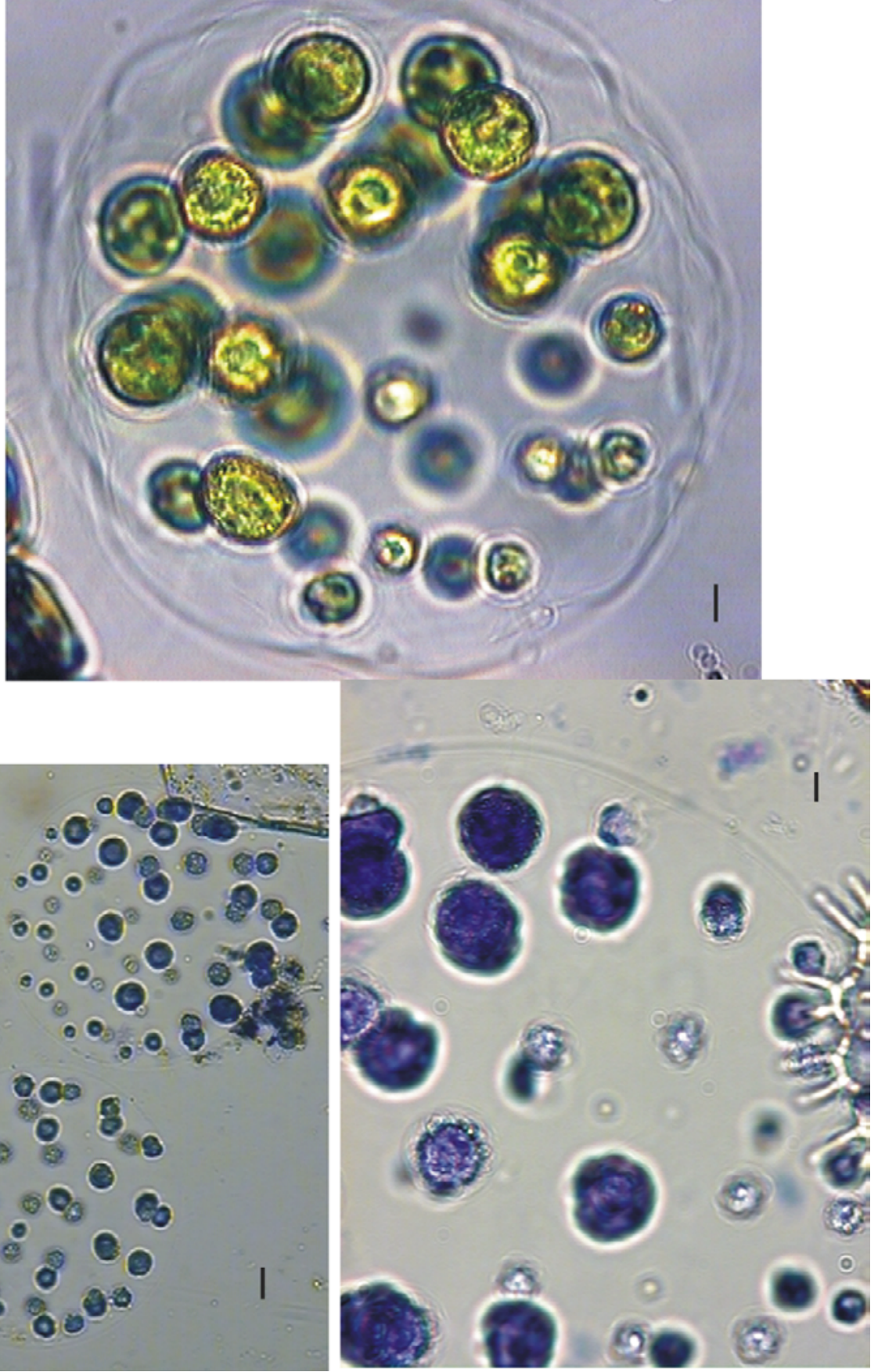

Fig. 6 Pleodorina californica Shaw; pictures at the bottom after staining with blue methylene. Scale bars: $10 \mu \mathrm{m}$. 
The species is known from Asia, Europe, as well as North and South America [1]. Yamagishiella unicocca occurs near Kharkiv [12,26], in Siberia [27], in the U. S. states of Indiana, Massachusetts and Oregon [28], in southern Brazil [23], in Singapore [29], in Germany in the Elde River [30], in Hungary in the Tisza River [15] and in Spain [31]. These taxa, originally described as Pandorina charkowiensis and E. unicocca, were recorded in the Vistula River in Poland by Uherkovich [17].

In the Vistula (along the distance from the town of Wyszogród up to the town of Toruń) and in WDR (in the main stream and in the marsh part), the species occurred between late March and November in 1996-2000 and was present at all sites [18-20]. At that time the temperature ranged from 10.6 to $24.0^{\circ} \mathrm{C}$. In the Ma reservoir, the species occurred in August 2010 ( 3 months after the flooding) - at a temperature ranging from 20.7 to $22.0^{\circ} \mathrm{C}$. In reservoir W1, it occurred in July and August
2010 when the temperature fluctuated within the range of $19.6-21.7^{\circ} \mathrm{C}$. In reservoir W3, it occurred in August 2010 when the temperature fluctuated within the range of $19.8-20.1^{\circ} \mathrm{C}$.

\section{Pleodorina californica Shaw}

Syn. Eudorina californica (Starr) Goldstein (Fig. 6)

Pleodorina californica is a coenobial green alga with oval or spherical colonies and the diameter of 50-190 $\mu \mathrm{m}$ with 128 , 64 or 32 cells. Gelatinous cover is homogeneous. Biflagellate cells are differentiated into somatic (small) cells of 7-9 $\mu \mathrm{m}$ and reproductive (large) cells of $12-20 \mu \mathrm{m}$. In the colonies from the Vistula River and the oxbow lakes, somatic cells accounted for 32 to $50 \%$ of all cells.

P. californica was recorded in Africa, Asia, Europe, North and South America [1]. P. californica occurs at few sites but is relatively common in the USA $[3,22,32]$. The species was also

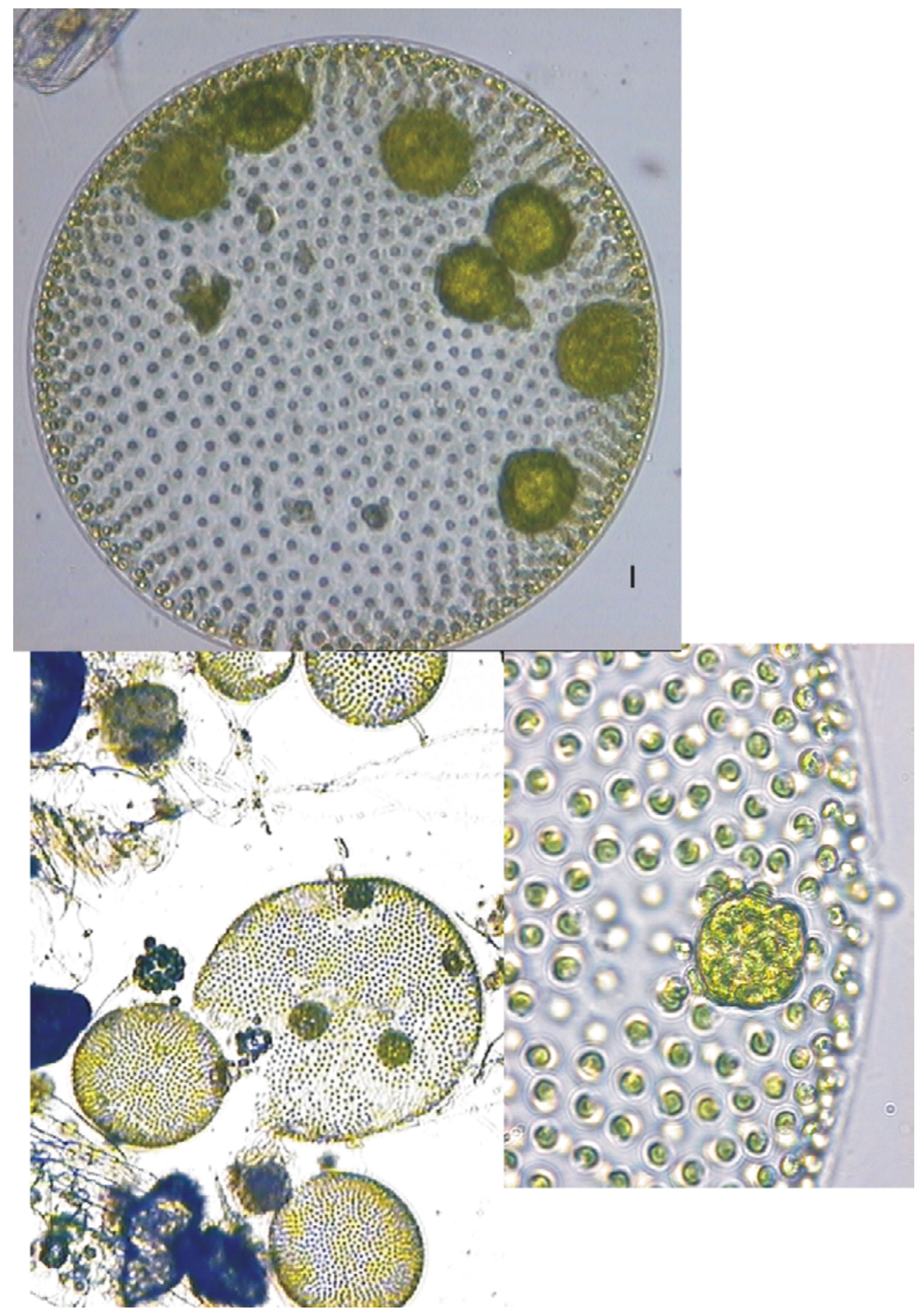

Fig. 7 Volvox aureus Ehrenberg. Scale bars: $10 \mu \mathrm{m}$. 
found on Java [33], in Venezuela [34] and in Ontario (Canada) [35], as well as in Australia and New Zealand [36]. In Europe, it was found in Ukraine [37], on the Iberian Peninsula [38], and in Romania [16,39].

This is the first information about the species occurrence in Poland. In the Włocławek Reservoir, P. californica occurred only once - on 07 August 1998. Later, it was recorded several times in the Vistula oxbow lakes in Torun. In the Prz. oxbow lake, which at that time was isolated from the Vistula River because of the very low water level in the river, the species occurred several times in August, September and October 2009. It occurred at a temperature of $22.3^{\circ} \mathrm{C}$, the concentration of N-NH $1.6 \mathrm{mg} \mathrm{dm}^{-3}$ and $\mathrm{N}-\mathrm{NO}_{3} 0.24 \mathrm{mg} \mathrm{dm}^{-3}$, and $\mathrm{P}_{-} \mathrm{PO}_{4} 0.3 \mathrm{mg} \mathrm{dm}^{-3}$ and was present till October when the temperature dropped to $11.5^{\circ} \mathrm{C}$, and the concentrations of biogenic elements were as follows: $\mathrm{N}-\mathrm{NH}_{4}$ $0.4 \mathrm{mg} \mathrm{dm}^{-3}, \mathrm{~N}_{-\mathrm{NO}_{3}} 0.48 \mathrm{mg} \mathrm{dm}^{-3}$, and $\mathrm{P}_{-} \mathrm{PO}_{4} 0.04 \mathrm{mg} \mathrm{dm}^{-3}$. In the Ma reservoir, the species occurred only once - on 25 August 2009 in similar thermal and chemical conditions $-20.8^{\circ} \mathrm{C}$ and the concentration of N-NH $40.34 \mathrm{mg} \mathrm{dm}^{-3}, \mathrm{~N}-\mathrm{NO}_{3} 0.18 \mathrm{mg} \mathrm{dm}^{-3}$ and $\mathrm{P}_{-} \mathrm{PO}_{4} 0.04 \mathrm{mg} \mathrm{dm}^{-3}$. In W1 and $\mathrm{W} 3$ reservoirs, $P$. californica occurred in July 2010, when the temperature fluctuated within the range of $20.8-21.2^{\circ} \mathrm{C}$. Biocoenoses of these reservoirs were in the process of regeneration after May inundation.

\section{Discussion}

In 1968, a total of 8 taxa were found in the seston of the Vistula River [17], which at present are included in Volvocaceae. Those are: Eudorina charkowiensis (syn. Pandorina charkowiensis [26]), E. cylindrica, E. elegans, E. illinoisensis, E. unicocca, Pandorina morum, Volvox aureus, V. globator.

Several of the aforementioned species were found during the research conducted in 1994-2010 in the lower Vistula and the oxbow lakes. Those were: Eudorina cylindrica, E. elegans, E. illinoisensis, E. unicocca (it is probably E. peripheralis and/ or Yamagishiella unicocca), Pandorina morum, Volvox aureus.

According to Nozaki et al. [25], it is impossible to distinguish between E. unicocca and Yamagishiella unicocca without genetic analysis ( $r b c \mathrm{~L}$ gene sequence) or observations of sexual reproduction (isogamy/anisogamy). Both species are identical in morphological terms. However, in further work Yamada et al. [24] report that number and distribution of contractile vacuoles, in all strains of Eudorina and Yamagishiella can be clearly distinguished two genera. Eudorina strains had several contractile vacuoles distributed over the entire surface of vegetative colony protoplasts, whereas Yamagishiella strains had only two contractile vacuoles near the base of the flagella.

Two species, E. unicocca and E. peripheralis have been separated from the species Eudorina unicocca. E. unicocca has characteristic gelatinous matrix divided into individual sheath covers of each cell. E. peripheralis differs from E. unicocca in lacking individual sheaths [24]. In disputed species, the gelatinous matrix is not divided, but unfortunately, contractile vacuoles are not visible in the preserved material. This makes it impossible to distinguish these two taxa - E. peripheralis and/ or Yamagishiella unicocca of material collected earlier.

Eudorina cylindrica, E. Illinoisensis and E. peripheralis and/ or Yamagishiella unicocca [10] are rare in Poland. P. californica from the genus Pleodorina is new to Poland - the species was first recorded in 1998 in the Włocławek Reservoir and then several times during the subsequent research in the Vistula oxbow lakes.
So far, six species from the genus Pleodorina were described: P. californica Shaw, P. japonica Nozaki, P. indica (Iyengar) Nozaki, P. sphaerica Iyengar [4] and P. starrii H. Nozaki et al. and $P$. thompsonii F. D. Ott et al. [5]. P. japonica, P. sphaerica, $P$. starrii and $P$. thompsonii were found only outside Europe. $P$. indica, originally described from India, Mexico and Argentina [9], was also found in Europe in the oxbow lakes of the Danube River [8], in the Malše River where in 2003 it caused a large-scale water bloom [32], and a year later, the species was reported from eutrophic ponds in the Czech Republic. Pleodorina californica, known mainly from the southern U. S. states and single sites in Europe, was also found in Poland in the Włocławek Reservoir and the Vistula oxbow lakes in Torun. This is the first publication about the presence of this species in Poland.

In order to confirm the identification of Eudorina peripheralis/Yamagishiella unicocca and Pleodorina californica found in the Vistula River and this oxbow lakes, a further morphological observations and genetic studies are required. Because of the small number of specimens and low incidence, genetic studies have not yet been carried out.

\section{Acknowledgments}

I am most grateful to employees of the Institute of Botany PAS in Cracow, in particular Dr. Jolanta Piątek for making available the material from the iconotheca of algae. This research was financed by State Committee for Scientific Research (KBN) under projects No. 6PO4G 04812 and 6PO4F 00713 and by Nicolaus Copernicus University - research projects No. 467-B UMK/2007 and 339-B UMK/2008. Many thanks to anonymous reviewers for comments and helpful suggestions on the manuscript.

\section{References}

1. Coleman AW. A comparative analysis of the Volvocaceae (Chlorophyta). J Phycol. 2012;48(3):491-513. http://dx.doi. org/10.1111/j.1529-8817.2012.01168.x

2. Nozaki H, Kuroiwa T. Ultrastructure of the extracellular matrix and taxonomy of Eudorina, Pleodorina and Yamagishiella gen. nov. (Volvocaceae, Chlorophyta). Phycologia. 1992;31(6):529-541. http://dx.doi.org/10.2216/ i0031-8884-31-6-529.1

3. Nozaki H. Flagellated green algae. In: Wehr JD, Sheath RG, editors. Freshwater algae of Northern America: ecology and classification. San Diego CA: Academic Press; 2002. p. 225-252. (Aquatic ecology).

4. Nozaki H, Kuroiwa H, Mita T, Kuroiwa T. Pleodorina japonica sp. nov. (Volvocales, Chlorophyta) with bacteria-like endosymbionts. Phycologia. 1989;28(2):252-267. http://dx.doi.org/10.2216/i0031-8884-28-2-252.1

5. Nozaki H, Ott FD, Coleman AW. Morphology, molecular phylogeny and taxonomy of two new species of Pleodorina (Volvoceae, Chlorophyceae). J Phycol. 2006;42(5):1072-1080. http://dx.doi. org/10.1111/j.1529-8817.2006.00255.x

6. Liss M, Kirk DL, Beyser K, Fabry S. Intron sequences provide a tool for high-resolution phylogenetic analysis of volvocine algae. Curr Genet. 1997;31(3):214-227. http://dx.doi.org/10.1007/s002940050198

7. Nozaki H, Ito M, Uchida H, Watanabe MM, Kuroiwa T. Phylogenetic analysis of Eudorina species (Volvocaceae, Chlorophyta) based on $r b c \mathrm{~L}$ gene sequences. J Phycol. 1997;33(5):859-863. http://dx.doi. org/10.1111/j.0022-3646.1997.00859.x

8. Angeler DG, Schagerl M, Coleman AW. Phylogenetic relationships among isolates of Eudorina species (Volvocales, Chlorophyta) inferred from 
molecular and biochemical data. J Phycol. 1999;35(4):815-823. http:// dx.doi.org/10.1046/j.1529-8817.1999.3540815.x

9. Kaštovský J, Hauer T, Mareš J, Krautová M, Bešta T, Komárek J, et al. A review of the alien and expansive species of freshwater cyanobacteria and algae in the Czech Republic. Biol Invasions. 2010;12(10):3599-3625. http:// dx.doi.org/10.1007/s10530-010-9754-3

10. Siemińska J, Wołowski K. Catalogue of Polish prokaryotic and eukaryotic algae. Cracow: W. Szafer Institute of Botany, Polish Academy of Sciences; 2003.

11. Kentzer A, Dembowska E, Giziński A, Napiórkowski P. Influence of the Włocławek Reservoir on hydrochemistry and plankton of a large, lowland river (the Lower Vistula River, Poland). Ecol Eng. 2010;36(12):1747-1753. http://dx.doi.org/10.1016/j.ecoleng.2010.07.024

12. Huber-Pestalozzi G. Das Phytoplankton des Süßwassers. In: Chlorophyceae (Grünalgen) Ordnung: Volvocales. Stuttgart: Schweizerbart Science Publishers; 1961. p. 744. (vol 5).

13. Uherkovich G. Über das Sommerplankton das Alterwassers von Mártély. Tiscia Szeged. 1967;3:13-20.

14. Uherkovich G. A Tisza lebegö paránynövényei (A Tisza fitoszesztonja) (Phytoseston of the Tisza). Szolnok: Damjanich Museum; 1971.

15. Kiss J. The algal flora and its seasonal aspects in the Körtvélyes and Mártély backwaters of the Tisza. Tiscia Szeged. 1982;17:51-65.

16. Cărăuș I. Algae of Romania. A distributional checklist of actual algae. Version 2.3 [Internet]. 2012 [cited 2013 May 3]; Available from: http://www. seaweedafrica.org/pdf/562DF96D13b4823893SWjO3A7893/50442.pdf

17. Uherkovich G. Über das Wisła-Phytoseston Zwischen Kraków und Tczew. Acta Hydrobiol. 1970;12(2-3):161-190.

18. Dembowska E. Phytoplankton of the Włocławek Reservoir during the years 1994-2000 [PhD thesis]. Toruń: Nicholas Copernicus University in Toruń; 2002.

19. Dembowska E. Summer phytoplankton in the Włocławek Reservoir. AUNC Limnol Pap. 2002;22:31-51.

20. Dembowska E. Tentative assessment of the phytoplankton in the Vistula between Płock and Torun (with the Włocławek Reservoir), Poland. AUNC Limnol Pap. 2005;24:19-43.

21. Grove WB. Pleodorina illinoiensis Kofoid in Britain. New Phytol. 1915;14(67):169-182. http://dx.doi.org/10.1111/j.1469-8137.1915.tb07184.x

22. Prescott GW. Algae of the western Great Lakes area with an illustrated key to the genera of desmids and freshwater diatoms. Revised edition. Dubuque IA: William C. Brown Publishers; 1961.

23. Menezes M, Bicudo CEM. Flagellate green algae from four water bodies in the state of Rio de Janeiro, Southeast Brazil. Hoehnea. 2008;35(3):435-468. http://dx.doi.org/10.1590/S2236-89062008000300012

24. Yamada TK, Miyaji K, Nozaki H. A taxonomic study of Eudorina unicocca (Volvocaceae, Chlorophyceae) and related species, based on morphology and molecular phylogeny. Eur J Phycol. 2008;43(3):317-326. http://dx.doi. org/10.1080/09670260701763484

25. Nozaki H, Ito M, Sano R, Uchida H, Watanabe MM, Takahashi H, et al. Phylogenetic analysis of Yamagishlella and Platydorina (Volvocaceae, Chlorophyta) based on $r b c$ L gene sequences. J Phycol. 1997;33(2):272-278. http://dx.doi.org/10.1111/j.0022-3646.1997.00272.x

26. Ettl H. Chlorophyta I. Phytomonadina. In: Ettl H, Gerloff J, Heynig H, Mollenhauer D, editors. Sußwasserflora von Mitteleuropa. Stuttgart: Gustav Fischer Verlag; 1983.

27. Komarenko LE, Vasileva II. Presnovodnye zelenye vodorosli vodoemov Iakutii. Moscow: Nauka; 1978.

28. Rayburn WR, Starr RC. Morphology and nutrition of Pandorina unicocca sp. nov. J Phycol. 1974;10(1):42-49. http://dx.doi. org/10.1111/j.1529-8817.1974.tb02676.x

29. Pham MN, Tan HTW, Mitrovic S, Yeo HHT. A checklist of the algae of Singapore. Singpore: Raffles Museum of Biodiversity Research, National University of Singapore; 2011.

30. Möller B, Pankow H. Beitrag zur Algenflora der Elde (Mecklenburg). Rostock: Wissenschaftliche Zeitschrift der Wilhelm-Pieck-Universität; 1973. (vol 22).

31. Cobelas AM, Gallardo T. Catálogo de las algas continentales españolas. IV. Chlorophyceae Wille in Warming 1884. Prasinophyceae T. Christensen ex Silva 1980. Acta Bot Malacit. 1986;11:17-38.

32. Znachor P, Jezberová J. The occurrence of a bloom-forming green alga Pleodorina indica (Volvocales) in the downstream reach of the River Malse (Czech Republic). Hydrobiologia. 2005;541(1):221-228. http://dx.doi. org/10.1007/s10750-004-5710-5

33. Wołoszyńska J. Das Phytoplankton einiger javanischer Seen, mit Berücksichtigung des Sawa-Planktons. Bull Acad Sci Crac. 1912;??:649-709.

34. Yacubson S. Catálogo e iconografia de las Cyanophyta de Venezuela. Bol Cent Invest Biol. 1974;11:1-143.

35. Duthie HC, Socha R. A checklist of the freshwater algae of Ontario, exclusive of the Great Lakes. Nat Can. 1976;103:89-109.

36. Day SA, Wickham RP, Entwisle TJ, Tyler PA. Bibliographic check-list of non-marine algae in Australia. Parkes: Australian Biological Resources Study; 1995. (Flora of Australia Supplementary 4).

37. Topachevskij AV, Masjuk NP. Presnowodnye wodorosli Ukrainskoj SSR. Kiev: Wyszsza Szk; 1984.

38. Sánchez C, Álvarez Cobelas J, Aboal Sanjurjo MM. Lista florística y bibliográfica de los clorófitos (Chlorophyta) de la Península Ibérica, Islas Baleares e Islas Canarias. Burgos: Asociación Española de Limnología; 1998.

39. Kiss A, Momeu L, Gudasz C, Péterfi LŞ. Preliminary studies on the algal communities occurring in the pond of the central park Cluj-Napoca (Transylvania, Romania). Contrib Bot. 2005;40:163-171. 